\title{
Storing Drinking-water in Copper pots Kills Contaminating Diarrhoeagenic Bacteria
}

\author{
V.B. Preethi Sudha', Sheeba Ganesan', G.P. Pazhani², T. Ramamurthy', \\ G.B. Nair², and Padma Venkatasubramanian'
}

\begin{abstract}
'Centre for Pharmacognosy, Pharmaceutics and Pharmacology, Institute of Ayurveda and Integrative Medicine (formerly Foundation for Revitalisation of Local Health Traditions), 74/2 Jarakabande Kaval, Yelahanka via Attur, Bangalore 560 0106, Karnataka, India and ${ }^{2}$ National Institute of Cholera and Enteric Diseases, P-33, CIT Road, Scheme XM, Beliaghata, Kolkata 700 010, West Bengal, India
\end{abstract}

\begin{abstract}
Microbially-unsafe water is still a major concern in most developing countries. Although many water-purification methods exist, these are expensive and beyond the reach of many people, especially in rural areas. Ayurveda recommends the use of copper for storing drinking-water. Therefore, the objective of this study was to evaluate the effect of copper pot on microbially-contaminated drinking-water. The antibacterial effect of copper pot against important diarrhoeagenic bacteria, including Vibrio cholerae O1, Shigella flexneri 2a, enterotoxigenic Escherichia coli, enteropathogenic E. coli, Salmonella enterica Typhi, and Salmonella Paratyphi is reported. When drinking-water ( $\mathrm{pH} 7.83 \pm 0.4$; source: ground) was contaminated with 500 $\mathrm{CFU} / \mathrm{mL}$ of the above bacteria and stored in copper pots for 16 hours at room temperature, no bacteria could be recovered on the culture medium. Recovery failed even after resuscitation in enrichment broth, followed by plating on selective media, indicating loss of culturability. This is the first report on the effect of copper on S. flexneri 2a, enteropathogenic E. coli, and Salmonella Paratyphi. After 16 hours, there was a slight increase in the $\mathrm{pH}$ of water from 7.83 to 7.93 in the copper pots while the other physicochemical parameters remained unchanged. Copper content $(177 \pm 16 \mathrm{ppb})$ in water stored in copper pots was well within the permissible limits of the World Health Organization. Copper holds promise as a point-of-use solution for microbial purification of drinking-water, especially in developing countries.
\end{abstract}

Key words: Bacteria; Copper; Diarrhoea; Drinking-water; Vibrio cholerae; India

\section{INTRODUCTION}

Providing safe drinking-water to the majority of the world's population, especially to those in developing countries, is still a major problem. Approximately a billion people lack access to safe drinking-water (1). Water and food contaminated with bacteria, viruses, and protozoa cause infectious diarrhoea. Diarrhoea is one of the leading causes of mortality and morbidity, especially in children of developing countries (2) and claims two million lives each year (3). The major aetiological agents

Correspondence and reprint requests should be addressed to:

Dr. Padma Venkatasubramanian

Centre for Pharmacognosy, Pharmaceutics and Pharmacology

Institute of Ayurveda and Integrative Medicine 74/2 Jarakabande Kaval, Yelahanka via Attur Bangalore 560 0106, Karnataka India

Email: padma.venkat@frlht.org OR

padmavenkatl@rediffmail.com Fax: +91080 28567926 that account for over a million diarrhoeal deaths per year, particularly in developing countries, are enterotoxigenic Escherichia coli (ETEC), rotavirus, Vibrio cholerae, and species of Shigella, which are spread through contaminated water and food or from person to person (4). In India, many states still have outbreaks of cholera. During 1996-2007, at least 222,038 individuals were affected by cholera (5). Shigellosis, also known as acute bacillary dysentery, is associated with complications, such as haemolytic-uraemic syndrome which can be fatal (6). Shigella flexneri causes approximately $10 \%$ of all diarrhoeal episodes among children aged less than five years (7). Infection with ETEC is associated with traveller's diarrhoea, and the rate of infection is higher in India compared to other developing countries (8). Among the viruses, rotaviruses are the most common cause of diarrhoea in infants and children. In Asia, rotaviruses are responsible for $45 \%$ of hospitalizations for severe infantile diarrhoea (9). Microbial quality, though only one of the parameters of safe drinking-water, is a major problem and is a cause of epidemics in developing 
countries. The existing community interventions to provide safe drinking-water to the people have many shortcomings, and studies have shown that point-of-use (PoU) household interventions contribute to $30-40 \%$ reduction in diarrhoeal diseases (10). Moreover, in countries such as India where only $28 \%$ of households have piped water (5), PoU interventions are a sustainable way to providing safe drinking-water.

Storing water in copper and silver pots finds mention in ancient texts of Ayurveda for purification of water (11). Our previous study provided laboratory evidence of the antibacterial activity of copper pot in distilled water (12). We had also reported the benefit of using a copper-based device, contrived by us, which was as effective as the pot but at a fraction of the cost (12). Since distilled water is slightly acidic ( $\mathrm{pH} 6.7 \pm 0.05$ ) which might enhance copper leaching, we have demonstrated the effect of copper pot in regular drinking-water $(\mathrm{pH}$ $7.83 \pm 0.4$ ) against important bacterial pathogenic strains that cause diarrhoea.

\section{MATERIALS AND METHODS}

\section{Bacterial strains}

$V$. cholerae $\mathrm{O} 1 \mathrm{IDH} 02474$ (VC), S. flexneri type 2a IDH 02196 (SF), Salmonella enterica Typhi 500865 (SET), and enterotoxigenic E. coli (LT+ST) IDH 01254 (ETEC) were obtained from the National Institute of Cholera and Enteric Diseases (NICED), Kolkata, India. S. Paratyphi A B/05 (SPT) was procured from the St. Johns Medical College, Bangalore, India and confirmed at NICED. Enteropathogenic E. coli E 2347 (EPEC) was obtained from the Christian Medical College (CMC), Vellore, India.

\section{Preparation of bacterial cultures}

Cultures from the nutrient agar culture-stab were streaked onto selective media, including eosin methylene blue (EMB) agar medium (HIMEDIA, Mumbai, India) for $E$. coli species, xylose lysine dextrose (XLD) medium (HIMEDIA) for Salmonella species, Henktoen enteric agar (HEA) medium (Difco, USA) for Shigella, and thiosulphate-citrate bile-salts sucrose (TCBS) medium (HIMEDIA) for $V$. cholerae, and were incubated at $37{ }^{\circ} \mathrm{C}$ for $16-18$ hours in a bacteriological incubator (IN 18 DF, Servewell Instruments Private Limited, Bangalore, India). After incubation, a single colony was picked and inoculated into $2 \mathrm{~mL}$ of Luria Bertani broth (Difco) and incubated for 16-18 hours in a bacteriological incubator at $37{ }^{\circ} \mathrm{C}$. This overnight culture was serially diluted in normal saline $(\mathrm{NaCl}, 0.85 \%)$ for inoculation in water.
Antibacterial activity of copper pot on drinkingwater inoculated with enteric pathogens

The experiment procedure followed was essentially as per Sudha et al. (12). Copper pots of 2-L capacity (test) purchased from local vendors were thoroughly cleaned and autoclaved each time before use. Presterilized 1-L glass bottles (Schott Duran, Mainz, Germany) acted as controls.

Water was collected from the tap (groundwater, pumped to the overhead tank) from the Microbiology Unit of FRLHT (Foundation for Revitalisation of Local Health Traditions), Bangalore and was autoclaved. The sterilized water was inoculated to $\sim 500$ colony-farming unit (CFU)/mL with seriallydiluted overnight culture of the diarrhoeagenic bacteria. The same was enumerated by spread plate method on nutrient agar (HIMEDIA). Two litre of inoculated water was poured into copper pots (2x2L) and one litre into each of the two presterilized Schott Duran bottles. After incubation at room temperature $\left(26 \pm 2{ }^{\circ} \mathrm{C}\right)$ for 16 hours, $100 \mu \mathrm{L}$ of samples was withdrawn, after mixing, from each container and plated on nutrient agar for the enumeration of bacteria. Resuscitation of sublethally-damaged cells was monitored by enrichment method (13). Three mL of test or control water sample was mixed with an equal volume of doublestrength peptone water (enrichment medium) and incubated for 24 hours at $37^{\circ} \mathrm{C}$. After incubation, the medium was observed for turbidity, and also a loopful of the enriched culture was streaked onto respective selective media as mentioned earlier and observed for growth after incubation for 24 hours at $37{ }^{\circ} \mathrm{C}$. All experiments were conducted three times with duplicates maintained each time.

Analysis of physical and chemical parameters of water

Tests and controls of the inoculated water were assessed before and after incubation for physicochemical properties, including $\mathrm{pH}$, turbidity, total dissolved solids (TDS), alkalinity, hardness, contents of chlorides and sulphates as per protocols of the Bureau of Indian Standards (14). The $\mathrm{pH}$ was measured using a $\mathrm{pH}$ meter (DI 707; Digisun Electronics, Hyderabad, India). Copper content was estimated using Spectroquant (Merck, Darmstadt, Germany), a commercially-available, ready-to-use kit, as described in Sudha et al. (12).

\section{RESULTS}

Antibacterial activity of copper pot on drinking-water inoculated with enteric pathogens

VC, SF, ETEC, EPEC, SET, and SPT inoculated into water could not be recovered on the specific 
growth medium as mentioned in methods (Table 1). In the control glass bottles, on the other hand, the number of bacteria inoculated either remained the same or slightly increased (Table 1). After incubation in the enrichment broth, there was no visible turbidity in the test samples, and no bacteria could be recovered when the enriched cultures were streaked onto selective media. With controls, turbidity in enrichment medium and subsequent growth of bacteria on selective medium were observed (Table 1), where VC exhibited as typical yellow colony on TCBS medium, SF as typical small green colonies on HEA medium, and Salmonella species as pink colonies with/ without black centre on XLD medium whereas ETEC and EPEC exhibited typical metallic sheen colonies on EMB agar medium. This indicates that the bacteria in the test samples were either completely killed or had lost their culturability on media. antibacterial activity of copper against pathogenic strains of SF, EPEC, and SPT. Copper pot is as active in regular drinking-water $(\mathrm{pH} 7.83 \pm 0.4)$ as that reported by us earlier (12) in distilled water ( $\mathrm{pH} 6.7 \pm 0.05$ ), and the level of copper leached in the former is far less $(177 \pm 16 \mathrm{ppb})$ than that in distilled water $(\sim 420$ $\mathrm{ppb})$. Other studies have shown that copper vessel is lethal to E. coli in water at different $\mathrm{pH}$ and temperature conditions, with the fastest inactivation occurring as the $\mathrm{pH}$ shifts away from neutrality and $35^{\circ} \mathrm{C}(15)$. Copper has also been shown to act, to a greater or lesser extent, on E. coli in the presence of organic and inorganic constituents in water (16). In laboratory experiments, copper has been shown to kill meticillin-resistant Staphylococcus aureus (17), Campylobacter jejuni, and S. enterica (18). Findings of these studies suggest that copper can act on a range of organisms under different conditions. It is still important to test the effect of copper on various sources of drinking-water under

Table 1. Effect of overnight storage of tap-water inoculated with diarrhoeagenic bacteria in copper pots and glass bottles

\begin{tabular}{|c|c|c|c|c|c|}
\hline \multirow{2}{*}{$\begin{array}{l}\text { Bacteria } \\
\text { inoculated }\end{array}$} & \multirow{2}{*}{$\begin{array}{c}\text { Before } \\
\text { incubation }\end{array}$} & \multicolumn{2}{|c|}{$\begin{array}{c}\text { Copper pots } \\
\text { After incubation }\end{array}$} & \multicolumn{2}{|c|}{$\begin{array}{c}\text { Glass bottles } \\
\text { After incubation }\end{array}$} \\
\hline & & $\begin{array}{l}\text { Bacterial count } \\
\quad(\mathrm{CFU} / \mathrm{mL})\end{array}$ & $\begin{array}{l}\text { Enrichment } \\
\text { culture }\end{array}$ & $\begin{array}{l}\text { Bacterial count } \\
\quad(\mathrm{CFU} / \mathrm{mL})\end{array}$ & $\begin{array}{l}\text { Enrichment } \\
\text { culture }\end{array}$ \\
\hline $\begin{array}{l}\text { V. cholerae O1 IDH } \\
2474\end{array}$ & $506 \pm 11$ & No growth & Not detected & $516 \pm 11$ & Detected \\
\hline $\begin{array}{l}\text { S. flexneri 2a IDH } \\
02196\end{array}$ & $533 \pm 28$ & No growth & Not detected & $530 \pm 26$ & Detected \\
\hline ETEC IDH 01254 & $513 \pm 23$ & No growth & Not detected & $866 \pm 83$ & Detected \\
\hline EPEC E2347 & $506 \pm 11$ & No growth & Not detected & $600 \pm 10$ & Detected \\
\hline $\begin{array}{l}\text { S. enterica Typhi } \\
500865\end{array}$ & $170 \pm 53$ & No growth & Not detected & $109 \pm 66$ & Detected \\
\hline S. Paratyphi A & $453 \pm 109$ & No growth & Not detected & $361 \pm 67$ & Detected \\
\hline
\end{tabular}

Physical and chemical parameters

The level of copper that had leached into the test samples was $177 \pm 16 \mathrm{ppb}$ which was well within the WHO limit of $2000 \mathrm{ppb}$ (Table 2). TDS, alkalinity, hardness, contents of chlorides and sulphates remained the same before and after incubation in both test and control samples, except that the $\mathrm{pH}$ had slightly increased from $7.83 \pm 0.4$ to $7.93 \pm 0.3$ in the test samples (copper pot) after incubation for 16 hours (Table 2 ).

\section{DISCUSSION}

None of the test pathogens was recovered from drinking-water stored in copper pots even after enrichment culture. This is the first report on the different field conditions. Safety of leached copper does not appear to be an issue since studies have shown that the current WHO guideline of $2 \mathrm{mg}$ $\mathrm{Cu} / \mathrm{L}$ is safe $(19,20)$, and the levels leached in the study were $\sim 1 / 20^{\text {th }}$ of the permissible limits. It has been observed in the present study that the other physicochemical parameters of drinking-water remain unchanged after copper intervention, which makes them amenable for public use.

We observed that the unrecovered bacteria in the test samples did not get resuscitated even after enrichment and plating on selective media. This indicates that they have lost culturability on nonselective medium and on enrichment and selective media. However, we still need to confirm whether 


\begin{tabular}{|c|c|c|c|c|}
\hline \multirow{2}{*}{ Parameter } & \multirow{2}{*}{$\begin{array}{l}\text { Permissible limit } \\
\left(\mathrm{BIS} / \mathrm{WHO}^{*}\right)\end{array}$} & \multirow{2}{*}{$\begin{array}{c}\text { Before } \\
\text { incubation }\end{array}$} & \multicolumn{2}{|c|}{ After incubation } \\
\hline & & & Test & Control \\
\hline Alkalinity (mg/L) & 600 & 25 & 25 & 25 \\
\hline Hardness (mg/L) & 600 & 280 & 280 & 280 \\
\hline Turbidity (NTU) & 10 & 0.47 & 0.47 & 0.47 \\
\hline $\mathrm{TDS}(\mathrm{mg} / \mathrm{L})$ & 2,000 & $700 \pm 49.5$ & $655 \pm 35.4$ & $690 \pm 14$ \\
\hline Chlorides (mg/L) & 1,000 & 35.45 & 35.45 & 35.45 \\
\hline Sulphates (mg/L) & 400 & 86.5 & 86.5 & 86.5 \\
\hline $\mathrm{pH}$ & $8.5-9.0$ & $7.83 \pm 0.4$ & $7.93 \pm 0.3$ & $7.83 \pm 0.4$ \\
\hline Copper content $(\mathrm{mg} / \mathrm{L})^{*}$ & 2 & $<$ DL 0.1 & $0.177 \pm 0.016$ & $<\mathrm{DL}$ \\
\hline
\end{tabular}

they have transformed into the viable but nonculturable (VBNC) state. VBNC is a state in bacteria where the cells do not grow onto routinelyemployed media but are still viable (21). VBNC bacteria have been studied using several methods, including alteration in temperature (22), use of enrichment medium (23), changes in the growth medium, using chick embryo yolk sack, passage through rabbit illeal loop (13), or co-culturing with eukaryotic cell cultures (21). VBNC bacteria have been observed using viable stains (22) and microscopy $(21,24,25)$.

Studies have shown that copper surfaces completely kill bacteria. E. coli inoculated on to copper coupons were completely killed. The studies concluded that the copper ions brought about complete killing of bacteria by membrane damage (26). However, the mechanism of action of copper on bacteria is not completely understood.

Although studies have shown the merits of copper surfaces for their use in improving public hygiene in healthcare facilities, the potential use of copper for the purification of drinking-water, especially in developing countries, has not been widely studied. Therefore, results of our study indicate that copper holds potential to provide microbially-safe drinking-water to the rural masses in developing countries. The use of copper pots in Indian households is common and is, therefore, likely to be socially accepted by the people. Its functioning is not dependent on fuel, electricity, replaceable filters, intensity of sunlight, etc. to operate or maintain it; it is simply a passive storage of water. This takes into account the conditions prevailing in rural villages and the urban slums of developing countries. The health benefit that can be achieved by using copper pot as a PoU water-purification device will far outweigh the cost of the pot, if divided over the members in a rural family, especially as it will be a one-time investment with no recurring costs. However, it is important to challenge its use under real-life conditions in the dynamics of the target households in developing countries to fully understand the limitations.

\section{ACKNOWLEDGEMENTS}

The study was supported by the ETC CAPTURED Programme, The Netherlands (Grant No. DGIS/D). The authors thank Mr. Darshan Shankar, Advisor, IAIM, for his constant encouragement.

\section{REFERENCES}

1. World Health Organization. Progress on sanitation and drinking-water: 2010 update. Geneva: World Health Organization, 2010. 55 p. (WHO/UNICEF 2010).

2. Kosek M, Bern C, Guerrant RL. The global burden of diarrhoeal disease, as estimated from studies published between 1992 and 2000. Bull World Health Organ 2003;81:197-204.

3. Fontaine $\mathrm{O}$, Kosek M, Bhatnagar S, Boschi-Pinto C, Chan, KY, Duggan C et al. Setting research priorities to reduce global mortality from childhood diarrhoea by 2015. PLOS Med 2009;6:e41. (doI:10.1371/Journal. Pmed.10000412).

4. Qadri F, Svennerholm AM, Faruque ASG, Sack RB. Enterotoxigenic Escherichia coli in developing countries: epidemiology, microbiology, clinical features, treatment, and prevention. Clin Microbiol Rev 2005; 18:465-83.

5. Kanugo S, Sah BK, Lopez Al, Sung JS, Paisly AM, Sur $\mathrm{D}$ et al. Cholera in India: an analysis of reports, 19972006. Bull World Health Organ 2010;88:185-91.

6. Sur D, Ramamurthy T, Deen J, Bhattacharya SK. Shig- 
ellosis: challenges \& management issues. Indian J Med Res 2004;120:454-62.

7. Niyogi SK. Shigellosis. J Microbiol 2005;43:133-43.

8. Shah N, Dupont HL, Ramsey JD. Global etiology of travelers' diarrhea: systematic review from 1973 to the present. Am J Trop Med Hyg 2009;80:609-14.

9. Grimwood K, Lambert SB. Rotavirus vaccines: opportunities and challenges. Hum Vaccines 2009;5:57-69.

10. Sobsey MD, Stauber CE, Casanova LM, Brown JM, Elliott MA. Point of use household drinking water filtration: a practical, effective solution for providing sustained access to safe drinking water in the developing world. Environ Sci Technol 2008;42:4261-7.

11. Sharma PV, Susruta samhita, V. 1. Sutra Sthana 45, 246 verse 13. Varanasi: Chaukamba Visva Bharati, 2004:418.

12. Sudha VBP, Singh KO, Prasad SR, Venkatasubramanian P. Killing of enteric bacteria in drinking water by a copper device for use in the home: laboratory evidence. Trans R Soc Trop Med Hyg 2009;103:819-22.

13. Oliver JD. Recent findings on the viable but nonculturable state in pathogenic bacteria. FEMS Microbiol Rev 2009;34:1-11.

14. Bureau of Indian Standards. Methods of sampling and test (physical and chemical) for water and wastewaster: IS:3025-1983 (part 5) reaffirmed 2002. New Delhi: Bureau of Indian Standards, 2002.

15. Sharan R, Chhibber S, Attri S, Reed RH. Inactivation and injury of Escherichia coli in a copper water storage vessel: effects of temperature and $\mathrm{pH}$. Antonie Van Leeuwenhoek 2010;97:91-7.

16. Sharan R, Chhibber S, Attri S, Reed RH. Inactivation and sub-lethal injury of Escherichia coli in a copper water storage vessel: effect of inorganic and organic constituents. Antonie Van Leeuwenhoek 2010;98:10315.

17. Noyce JO, Michels H, Keevil CW. Potential use of cop- per surfaces to reduce survival of meticillin-resistant Staphylococcus aureus in the healthcare environment. J Hosp Inf 2006;63:289-97.

18. Faúndez G, Troncoso M, Navarrete P, Figueroa G. Antimicrobial activity of copper surfaces against suspensions of Salmonella enterica and Campylobacter jejuni. BMC Microbiol 2004;4:19.

19. Pettersson R, Rasmussen F, Oskarsson A. Copper in drinking water: not a strong risk factor for diarrhoea among young children. A population-based study from Sweden. Acta Paediatr 2003;92:473-80.

20. Araya M, Olivares M, Pizarro F, Llanos A, Figueroa G, Uauy R. Community-based randomized double-blind study of gastrointestinal effects and copper exposure in drinking water. Env Hea Pers 2004;112:1068-73.

21. Senoh M, Ghosh-Banerjee J, Ramamurthy T, Hamabata T, Kurakawa T, Takeda $\mathrm{M}$ et al. Conversion of viable but nonculturable Vibrio cholerae to the culturable state by co-culture with eukaryotic cells. Microbiol Immunol 2010;54:502-7.

22. Kell DB, Kaprelyants SA, Weichart DH, Harwood CR, Barer MR. Viability and activity in readily culturable bacteria: a review and discussion of the practical issues. Antonie Van Leeuwenhoek 1998;73:169-87.

23. Ordax M, Marco-Noales E, Lo’Pez M, Biosca EG. Survival strategy of Eerwinia amylovora against copper: induction of the viable-but-nonculturable state. $A p p$ Environ Microbiol 2006;72:3482-8.

24. Chaiyanan S, Chaiyanan S, Huq A, Maugel T, Colwell RR. Viablity of the nonculturable Vibrio cholerae O1 and O139. System Appl Microbiol 2001;24:331-41.

25. Zhong L, Chen J, Zhang XH, Jiang YA. Entry of Vibrio cincinnatiensis into viable but nonculturable state and its resusucitation. Lett App Microbiol 2009;48:247-52.

26. Espírito Santo C, Lam EW, Elowsky CG, Quaranta D, Domaille DW, Chang CJ et al. Bacterial killing by dry metallic surfaces App Environ Microbiol 2011;77:794802. 